\title{
(6) 高分子科学最近の進歩
}

\section{強誘電性高分子の 非線形誘電現象}

\section{池田 進}

Susumu Ikeda, 山形大学工学部

\section{1.はじめに}

有限の大きさの系の物理的応答は, 大抵の場合, 刺 激が大きくなると共に飽和の傾向を示す。こういう意 味での非線形を弱い非線形性というとすると1)，要素 間の協力的相互作用が強く, 刺激と応答の関係にヒス テリシスが伴うような場合は強い非線形性があると言 える，このような系では，協力的相互作用エネルギー とエントロピーの競合で熱力学的な相転移が生じる. 強磁性や強誘電性はその典型的例である．最近高分子 物質にも強誘電性を示すものが発見され，その非線形 物性が研究されている。ここでは, 著者等の研究を中 心に, 高分子の強誘電性の発現と直接関係する誘電現 象の非線形性に視点を絞って最近の研究を紹介す る2). 2.〜4. では非線形誘電率と相転移の関係を，5. では非線形応答と分極反転との関係を論じる。

\section{2. 非線形誘電率と熱力学ポテンシャル}

分極 $P$ と外場 $E$ の関係は, 系の形状をフィルム状 とし, 分極と電場の方向をフィルムに垂直な方向に限 ると,

$$
P=P_{\mathrm{s}}+\chi E+\varepsilon_{2} E^{2}+\varepsilon_{3} E^{3}+\cdots
$$

と書ける。 $\chi$ は線形感受率, $\varepsilon_{n}$ は $n$ 次の非線形誘電 率である.このような系の未知の係数 $\varepsilon_{n}$ は入力とし て周波数 $f$ の正弦波電場を入れ出力をフーリエ変換 してnf 成分を取り出すことによって求めることがで きる.

一方，強誘電体の系の状態を規定する秩序パラメー ターには自発分極 $P_{s}$ をとることができ，その系の状 態変化を規定する熱力学ポテンシャル（試料が自由に

Nonlinear Dielectric Phenomena of Ferroelectric Polymers
変形できる実験条件では弾性 Gibbs 関数) は分極 $P$ で展開して $P^{8}$ 以上を省略すると，次のように書け る).

$$
\begin{aligned}
G-G_{0}= & (1 / 2) \beta\left(T-T_{0}\right) P^{2}+(1 / 4) \gamma P^{4} \\
& +(1 / 6) \delta P^{6}
\end{aligned}
$$

$G_{0}$ は分極に依存しない項で $\beta, \gamma, \delta, T_{0}$ は定数であ る.このポテンシャルは図 1 のように温度変化し相転 移を説明できる，この場合，強誘電性の起源が必ずし も双極子間の相互作用ではなくても（その場合には $P$ が真の秩序パラメーターではない）真の秩序パラ メーターと分極の結合項を考慮に入れることにより， 形式的に(2)式のような表現を作ることができる.

(2)式で, 熱力学ポテンシャル $G$ が $P^{2}$ のみの関数 だとすると，その係数の逆数である線形感受率のみて 系を記述することができる。しかし $G$ 中の高次項が 効いてくると，誘電率の非線形部分も有効になる．例 えば(1)式と(2)式から $\varepsilon_{n}$ を導くことができ，(2)式の 非調和項がなければ，非線形誘電率も必要なくなるこ とが容易にわかる。（2）式の係数のうち $T$ が $T_{0}$ 以下 になるか， $\gamma$ が負になることによってこのポテンシャ ルには $P=0$ 以外にもう一つの極小值が生じる．その 極小值の分極の值が自発分極であり，(2)式の高次項 の存在と直接結び付いている．図 1 を見たとき，系の 状態が $P=0$ にあり，系に対称中心のあるときには， 分極の摇らぎやすさは分極変化の正負に対して対称で あるが，系の状態が $P=P_{\mathrm{s}}$ にある場合はその対称性 が失われることがわかる．したがって，前者の場合に は(1)式の $E^{2}$ の項以下偶数べきの項は 0 になるべき なので偶数次の誘電率は消え, 後者の場合それは有限 の值を持つ.したがって二次の非線形誘電率 $\varepsilon_{2}$ は系 の分極の状態に敏感な誘電率といえる。

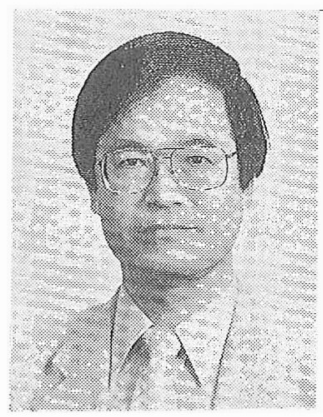

池田 進 山形大学工学部高分 子材料工学科 (992 米沢市城南 4-3-16）教授，工博 1968 年金沢大大学院理学研究 科修士課程物理学専攻修了 1968 年山形大工学部助手, 1981 年助教授, 1989 年教授. 専門は高分子物性，強誘電性高 分子の研究.

〈趣味〉将棋, スキー 


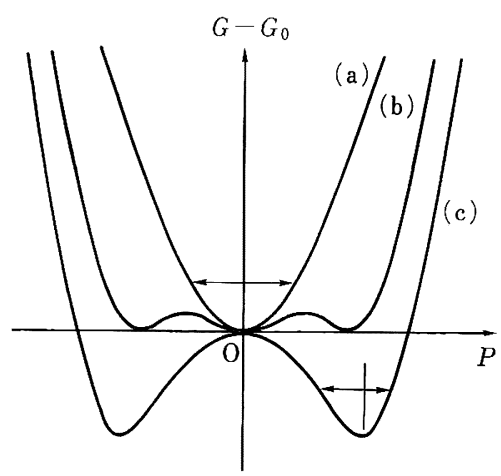

図 1 熱力学ポテンシャル

\section{3. フッ素系高分子の強誘電性}

$\mathrm{VDF}$ (フッ化ビニリデン) と TrFE（トリフルオロ エチレン) または $\mathrm{TeFE}$ (テトラフルオロエチレン) ${ }^{4)}$ との共重合体はいずれも強誘電性高分子になり, 概ね 似かよった性質を持つので，ここではよく調べられて いる VDF-TrFE 共重合体を取り上げる。

この共重合体の強誘電相での自発分極はVDF 基の 持つ永久双極子が配向することによって生じる，強誘 電相は主鎖がすべてトランス結合からなる平面ジグザ グ構造なので，外場による分極反転は，分子鎖にそっ たキンクの伝播によって起こると考えられている5). また相転移は平面ジグザグ状分子鎖にゴーシュ配位が 混入することによって生じる6).

よく知られている折りたたみ構造を取る高分子結晶 中の分子鎖を想定すると ${ }^{7}$ ，その分子鎖方向に直角に ついた双極子がマイクロ秒程度の時間で反転するとは なかなか信じられないが, 分極反転スイッチング現象 や $D-E$ ヒステリシスの測定 ${ }^{8)}, \mathrm{X}$ 線異常散乱の実験 ${ }^{91}$ などでごく当然のこととして認められ始めている。さ らにこの高分子の強誘電性のおもしろさはその共重合 比依存性にある.VDF 含有率の低い共重合体の示す 強誘電転移は熱力学的相転移とはいえないブロードな ものであるが，それはVDF 含有量の増加とともに鋭 くなっていく. 50 数\%以上の VDF を含む共重合体で は熱ヒステリシス（昇温時の相転移温度と降温時の相 転移温度の差）を伴う一次相転移に変わり，しかもそ の熱ヒステリシスは, 融点との関係で相転移がみられ なくなる約 $80 \%$ VDF 含有率の系まで増加してい く ${ }^{10)}$.このような強誘電相転移挙動のもっとも簡単な 解釈はこの共重合体の相転移が共重合比とともに二次 転移から一次転移へと変化していくと考えることであ る.（2)式の自由エネルギーの係数の符号と相転移の 次数との間には, 簡単な関係があり, 非線形誘電率を

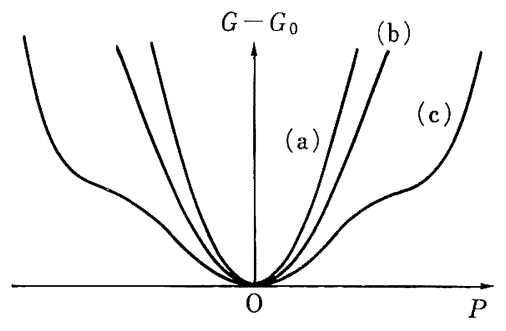

$\beta$ は三つとも同じ.（a） $\gamma>0$ (b) $\gamma=\delta=0$ (c) $\gamma<0$ とする.（b) では $\varepsilon_{3}=0$ だから（a）では $\varepsilon_{3}<0$ (c) では $\varepsilon_{3}>0$ になる.

図 2 常誘電状態の熱力学ポテンシャル

介してそれを決めることができる。

\section{4. 相転移の次数と非線形誘電率}

強誘電相転移の次数は, 現象論的に(2)式の熱力学 ポテンシャルの係数の符号と関係する. 今 (2) 式の係 数で $\beta, \delta$ を正の値とする. $\beta$ の正值は系が高温で常 誘電状態, 低温で強誘電状態になることを意味してお り, $\delta$ の正符号は分極の最高べきのエネルギー項が正 にならないと自発分極が有限にならないからである。 この場合, 相転移は $\gamma$ が負なら一次相転移に, 正な ら二次の相転移になる ${ }^{3)}$. この係数 $\gamma$ の符号は三次の 非線形誘電率 $\varepsilon_{3}$ の符号に直接反映する. $\gamma$ の正負に よらず，温度が $T_{\mathrm{c}}$ 以下の強誘電状態では， $\varepsilon_{3}$ の符号 は正になり, 常誘電状態では $\gamma$ が正の場合は $\varepsilon_{3}$ は負 に, $\gamma$ が負の場合は $\varepsilon_{3}$ が正になることは図 2 から推 定できる.したがって，相転移が一次の場合は $\varepsilon_{3}$ の 符号は変化せず，相転移が二次の場合は相転移温度 で， $\varepsilon_{3}$ の符号が変化することになる ${ }^{11), 12)}$. 現在まで の $\varepsilon_{3}$ の温度依存性の測定では ${ }^{11), 13), 14)}, 52 / 48(\mathrm{VDF} /$ TrFE）共重合体では符号が反転し，73/27では符号 の変化がないことがわかっている。このことはこの共 重合体が VDF 含有率の増加とともに二次的相転移を 経て, 一次相転移をする系に変化することを裏づけて いる。

この事情は二次の非線形誘電率 $\varepsilon_{2}$ の残留分極依存 性からも伺える。（3)式は(1)，(2)式から導かれる二 次の非線形誘電率 $\varepsilon_{2}$ の表現である.

$$
\varepsilon_{2}=-\left(3 \gamma+10 \delta P_{\mathrm{s}}^{2}\right) P_{\mathrm{s}} \chi^{3}
$$

いま結晶が，反対方向を向いた自発分極を持つ 2 種類 の領域でできているとする（このような系は分極反転 を数回繰り返した後反転途中で印加電場を切ることで 近似的に実現できる)，そのとき(3)式は次のようにな る $^{15)}$.

$$
\varepsilon_{2}=-\left(3 \gamma+10 \delta P_{\mathrm{s}}^{2}\right) P_{\mathrm{r}} \chi^{3}
$$




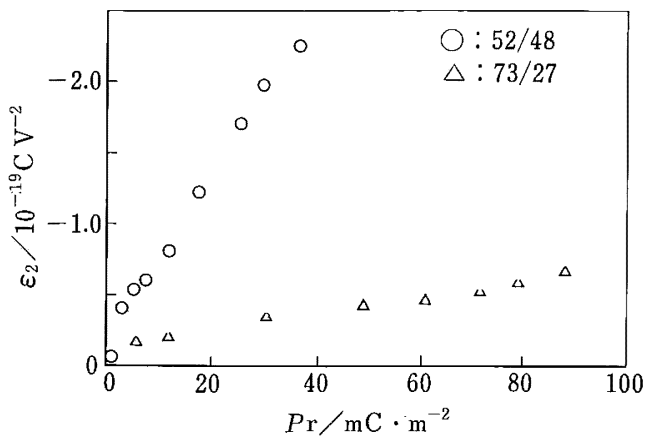

図 $3 \mathrm{VDF} / \mathrm{TrFE}$ 共重合体の $\varepsilon_{2}-P_{\mathrm{r}}$ 関係

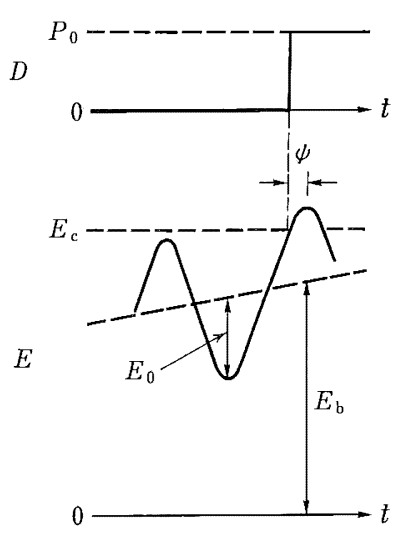

図 4 バイアス電場（三角波電場）と測定用正弦波電場 の和が抗電場 $\boldsymbol{E}_{\mathrm{c}}$ になったときの階段関数的応答
この式の $P_{\mathrm{s}}$ は結晶の自発分極， $P_{\mathrm{r}}$ は二つの領域の 体積比の差で決まる試料の残留分極を意味する，この ような $\varepsilon_{2}$ の $P_{\mathrm{r}}$ 依存性を $\mathrm{VDF} / \mathrm{TrFE}$ 共重合体の $52 /$ 48, 73/27について測定した結果が図3である ${ }^{11)}$. $52 / 48$ の傾斜が $73 / 27$ のそれに比べてはるかに大き い.この結果を理解するのに，52/48の $\gamma$ が正，73/ 27 の $\gamma$ が負と考えるのが最も簡単である.これは $\varepsilon_{3}$ の温度依存性から得られた結論と一致している。

(2)式の $\gamma, \delta$ が温度変化しないとする以上の議論は 最も簡単なものであり，現実の系がこれから逸脱する ことは十分にあり得る．この点に関しては $65 / 35$ の転 移とのからみで古川らの議論がある11),13).

寺岡らは, 以上のような平衡論以外に, 非線形緩和 も考慮に入れることができるように，場に非線形性を 導入し，二準位モデルに適用した。この場合にも場の 非線形性を表現する係数と相転移の間に一定の関係が 得られ，実験との比較から各共重合体における熱履歴 の有無を説明することができる ${ }^{16)}$.

\section{5. アモルファス高分子の分極反転現象}

シアン化ビニリデンと酢酸ビニルの交互共重合体は 大きな压電性を示すが，その構造はアモルファスであ る ${ }^{17)}$.この共重合体の压電性はシアノ基のもつ永久双 極子が配向することによる残留分極から生じることが 確認されている。すなわち，構造はアモルファスであ るが双極子の配向に関してある秩序が生じていること になる．このような分極形成には二種類の可能性があ り,一つは強誘電体のもつ自発分極であり, もう一つ はエレクトレットとよばれる誘電体が示す凍結した残 留分極である．前者の機構が確認されれば初のアモル ファス強誘電体ということになる ${ }^{18)}$. シアン化ビニリ デンの残留分極がこのどちらのタイプであるかは興味 ある問題である。このような事情を明らかにするため
には通常 $D-E$ ヒステリシス曲線の測定が行われる。 しかしこの場合には，分極反転が生じるような温度域 でもその反転時間は長く, 電場を超低周波で振る必要 があるため, 分極変化による電流が直流伝導電流の影 響を受けて, 解析可能な $D-E$ ヒステリシスを得るの はなかなか難しい. そこで $D$ の代わりに分極の方向 に敏感な二次の非線形誘電率 $\varepsilon_{2}$ を測定して $\varepsilon_{2}-E$ 関 係の解析を行う方法が有力である ${ }^{19}$.

超低周波（約 $10^{-4} \mathrm{~Hz}$ ) で電場振幅の大きい $\left(E_{\mathrm{c}}\right.$ 以 上）三角波で分極の状態を変えながら，低周波（ $f=5$ $\mathrm{Hz}$ 程度) で電場振幅の小さい正弦波入力に対する応 答加 $2 f$ 成分を抽出することにより, 分極の反転を 観測することができる. 図 4 にみられるように，二つ の電場の和がある一定の電場 $E_{\mathrm{c}}$ に達したときに, 分 極量 $P_{0}$ だけの階段関数的分極反転が生じるとすると, このときの電気変位の二次のフーリエ成分は, 次式の ように書ける.

$$
\begin{aligned}
& D_{2}{ }^{\prime}=\left(-P_{0} / 2 \pi\right) \sin 2 \psi \\
& D_{2}{ }^{\prime \prime}=\left(P_{0} / 2 \pi\right)(\cos 2 \psi-1)
\end{aligned}
$$

これは図 5 のようになる。これを正弦波入力振幅の 二乗で割ることでみかけの $\varepsilon_{2}$ を得ることができる. $\mathrm{VDF} / \mathrm{TrFE}(73 / 27)$ でこの実験をやった結果を図 5 に示す. $E$ が 0 の近傍で観測される $\varepsilon_{2}$ は分極と反対 符号をもつ(4)式で決まる二次の誘電率であり， $E_{\mathrm{c}}$ 近 傍で観測される $\varepsilon_{2}$ の振舞いは図 6 で与えられる分極 反転現象の際の電気変位の二次のフーリエ成分であ る. VDCN/VAc 共重合体の場合も VDF/TrFE ほど 顕著ではないが $T_{\mathrm{g}}$ よりかなり低温でも分極反転が認 められ， $\varepsilon_{2}^{\prime \prime}$ のピークの位置から抗電場 $E_{\mathrm{c}}$ を求める ことができる ${ }^{199} . E_{\mathrm{c}}$ の存在は VDCN/VAc の分極反 


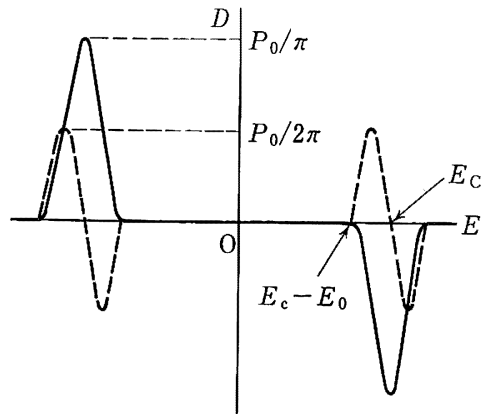

実線: $D_{2}{ }^{\prime}$ 破線: $D_{2}{ }^{\prime \prime}$

図 5 (5)，(6)式による $D-E$ 関係

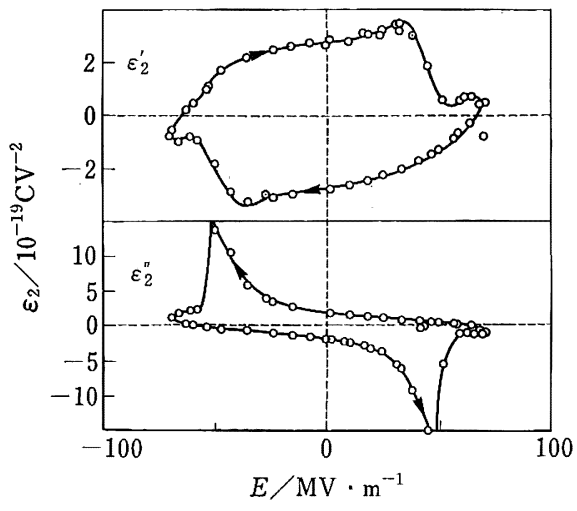

図 $6 \mathrm{VDF} / \mathrm{TrFE}(73 / 27) \sigma \varepsilon_{2}-E$ 関係
転がある程度の協同性をもっていることを意味してい る.

古川らは VDCN 系共重合体に関して三次の非線形 誘電緩和スペクトルを実験的に求め ${ }^{20)}$ ，非線形緩和の 理論にしたがって解析した ${ }^{21)}$ 。その結果, VDCN/ VAc 共重合体では $T_{\mathrm{g}}$ 以上で双極子間に相関のある 30 個程度の集団が運動の単位になっており，分子間 の相互作用の強い系であると推定している。これによ れば， $T_{\mathrm{g}}$ 以上で三次の誘電緩和強度 $\Delta \varepsilon_{3}$ は負である. Wang らによれば18)， $T_{\mathrm{g}}$ 以下では $\varepsilon_{3}$ は正だから， $T_{\mathrm{g}}$ で符号の反転が起こっている。しかし，さきに述べた $\varepsilon_{3}$ の符号と強誘電性の関係は強誘電状態では $\varepsilon_{3}>0$ は なりたつが, $\varepsilon_{3}>0$ だからといって系が強誘電状態で あるとは限らない，この点に関しては，強誘電性の定 義とも関係する，より詳しい研究が必要と思われる。

\section{6. おわりに}

この稿は $D-E$ ヒステリシスやスイッチング現象の 研究を含んでいない。これらの非線形誘電現象から非 線形応答そのものを抽出する形の研究のみを取り上げ た.このような形の誘電現象の研究は, 応用と直結し た光学の分野と比べるとはるかに量も少なく歴史も浅 い. しかし，測定手段の進歩がこの種の測定を著しく 容易にしつつあることと, 非晶, 非平衡, 非線形と “非”のつく物性の研究がさかんになっていることが あいまって，急速な発展が予想できる。

\section{文献}

1）鈴木増雄: $E L A N, 87-3,9$ (1987)

2）池田 進, 和田八三久: 静電気学会誌, 11, 2 (1987)

3）三井利夫，達崎 達， 中村英二：強誘電体，槙書店 (1969) 2 章

4) A.J. Lovinger: Jpn. J. Appl. Phys., 24-2, 18 (1985)
5) H. Dvey-Aharon, J.J. Alukin, P.L. Taylor, A.J. Hopfinger: Phys. Rev., B21, 3700 (1980)

6) K. Tashiro, K. Takano, M. Kobayashi, Y. Chatani, H. Tadokoro: Ferroelectrics, 57, 297 (1984)

7) M.G. Broadhurst, G.T. Davis, J.E. McKinney, R.E. Collins: J. Appl. Phys., 49, 4992 (1978)

8）小田島昷, 高瀬義彦, 高橋伸幸: 静電気学会誌, 5,312 (1981)

9) Y. Takahashi, Y. Nakagawa, H. Miyaji, K. Asai : J. Polym. Sci. Polym. Lett. Ed., 25, 153 (1987)

10) K. Koga, H. Ohigashi : J. Appl. Phys., 59, 2142 (1986)

11) S. Ikeda, H. Kominami, K. Koyama, Y. Wada: J. Appl. Phys., 62, 3339 (1987)

12) S. Ikeda, H. Kominami, K. Koyama, Y. Wada : Ferroelectrics, 76, 427 (1987)

13) T. Furukawa: Phase Transitions, 18, 143 (1989)

14) Y. Takase, A. Shibano, A. Odajima: Rept. Prog. Polym. Phys. Jpn., 29, 365 (1986)

15) S. Ikeda, H. Suzuki, K. Koyama, Y. Wada : Polym. J., 19, 681 (1987)

16) I. Teraoka, Y. Saito, R. Hayakawa: Polym. Prep. Jpn., 37, 2237 (1988)

17) S. Tasaka, K. Miyasato, M. Yoshikawa, S. Miyata, M. Ko: Ferroelectrics, 57, 267 (1984)

18) T.T. Wang, Y. Takase: J. Appl. Phys., 62, 3466 (1987)

19) S. Ikeda, H. Kiba, M. Kutani, Y. Wada : Jpn. J. Appl. Phys., 28, 1871 (1989)

20) T. Furukawa, M. Tada, K. Nakajima, I. Seo : Jpn. J. Appl. Phys., 27, 200 (1988)

21) O. Nakada: J. Phys. Soc. Jpn., 15, 2280 (1960) 